\title{
Does income redistribution impede innovation?
}

\author{
Michal Brzezinski \\ Faculty of Economic Sciences \\ University of Warsaw, Dluga 44/50, 00-241 Warsaw, Poland \\ mbrzezinski@wne.uw.edu.pl
}

\begin{abstract}
Economic inequalities have been increasing in many countries since the 1980s provoking calls for more income redistribution. One argument against increased redistribution is that it could hamper innovation and technological progress. To the best of our knowledge, this is the first paper that empirically investigates the relationship between government redistributive policies at the top of income distribution and innovative activity in a panel of countries. We use new, high-quality and cross-country comparable panel data on income redistribution from distributional national accounts. The sample covers 34 advanced and emerging countries over 19802010. We do not find any negative impact of the redistributive effect on innovation in the crosscountry setting. This result is robust to the use of various measures of income redistribution and patent-based indicators of innovation (patent counts, patent citations and patent originality).
\end{abstract}

Keywords: inequality, top income shares, Distributional National Accounts (DINA), World Inequality Database, redistribution, innovation, patent indicator, panel data

JEL Classification: O30, O38, D31, H31, I38

\section{Introduction}

Many recent studies document that income inequality has been rising since the 1980s within many of the advanced and emerging countries (OECD 2015; Alvaredo et al. 2018; Chancel 2019). This could potentially have negative consequences for economic growth (Berg et al. 2018) and several other socio-economic phenomena such as health, family formation, crime, intergenerational mobility, trust or populism (Nolan and Valenzuela 2019), but the causal impact of inequality on social outcomes in hard to establish empirically. Responding to growing inequalities many economists and policymakers started to call for increased income redistribution through higher taxes and transfers (Piketty 2014; Stiglitz 2012; Ostry et al. 2016). Surprisingly, while the link between inequality and innovation has been a subject of an intense debate (Tselios 2011; Antonelli and Gehringer 2017; Aghion et al. 2019; Benos and Tsiachtsiras 2019), the impact of income redistribution on innovation has so far received no attention. The theoretical effect of redistributive policies on innovation seems to be ambiguous. ${ }^{1}$ On the one hand, one may expect that financing redistributive transfers using higher (and possibly more progressive) income taxes lowers incentives to innovate (especially among the top income earners) or motivates innovators to shift their activities to jurisdictions with lower tax rates. On the other hand, higher redistribution can have a pro-innovation effect if the social transfers are directed at increasing the supply of graduates in STEM fields or improving the chances of becoming

\footnotetext{
${ }^{1}$ Similarly, economic theory does not imply whether income redistribution is unequivocally good or bad for economic growth (Berg et al. 2018; Woo 2020).
} 
inventors among talented persons with disadvantaged backgrounds. Therefore, the overall effect of redistribution on innovation is unknown a priori and should be verified empirically. However, empirical research on the impact of redistribution on innovation has been ruled out so far due to the lack of appropriate data.

In this paper, we provide a first cross-country analysis of the impact of redistributive tax and transfer policies on countries' innovative activity measured using patent-based indicators of innovation. We use novel data on income redistribution coming from the Distributional National Accounts (DINA) that provide cross-country comparable distributional statistics based on the combined data from household surveys, income tax sources and national accounts (Alvaredo et al. 2020a, b). The DINA offers several advantages over the alternative data sets based usually only on data from household surveys. It relies on data from tax returns to cover top incomes much more reliably than alternatives. Being consistent with national accounts, the DINA covers all forms of taxes and transfers which are usually missed in survey-based data (such as in-kind redistribution or indirect taxes). It allows also to compute measures of redistribution at the top of the income distribution. This feature is particularly well-suited for measuring the impact of redistribution on innovation as many of innovators are top-income earners.

Our sample covers 34 advanced and emerging countries over 1980-2010. Using dynamic panel models we do not find any negative impact of various income redistribution indices on countries' innovative activity as measured by several patent-based indicators. This outcome is robust to extensive robustness checks.

\section{Income inequality, redistribution and innovation}

Income redistribution is closely linked to income inequality as it can be defined as the difference between inequality of the pre-tax pre-transfer income distribution and inequality of the post-tax post-transfer income distribution. Most of the research on the complex links between inequality, redistribution and innovation has focused so far on estimating the impact of innovation on inequality. Innovation can affect income inequality via many channels. ${ }^{2}$ Aghion et al. (2019) show theoretically in a Schumpeterian growth model that both higher entrant innovation rate and higher incumbent innovation rate are associated with increased entrepreneurs' share of income, which assuming that at least some of the top-income earners are successful innovators translates into higher top income inequality ${ }^{3}$. Empirically, Aghion et al. (2019) found that innovation causes higher (pre-tax pre-transfer) top income shares in a panel of US states. Lee (2011) obtained a positive link between innovation and inequality measured on the regional level in Europe over 1996-2001, while Law et al. (2020) found the same result in a panel of developed countries over 1990-2015. On the other hand, Antonelli and Gehringer (2017) and Benos and Tsiachtsiras (2019) found that innovation is related to lower inequality in a cross-country setting. These conflicting results are probably related to different choices of the unit of analysis (countries vs within-country regions), as well as to the use of different measures of innovation and inequality.

Much smaller literature explored the impact of income inequality on innovation. Aghion et al. (2019) have argued that higher top income inequality can encourage more innovation. In general, the link works through market size effect and price effect (Tselios 2011). The former effect means that unequal income distribution creates only small markets for new products that develop slowly because there are few consumers able to buy innovative products. On the other hand, inequality can boost innovation if the richest consumers have a very high willingness to pay for innovative goods and services. Empirically, Tselios (2011) found a positive impact of inequality on innovation in a panel of European regions over the period 1995-2000. However,

\footnotetext{
${ }^{2}$ For a complete review of this literature, see De Palo et al. (2018) and Benos and Tsiachtsiras (2019).

${ }^{3}$ See also Jones and Kim (2018) for a different Schumpeterian model of top income inequality.
} 
the study did not control for income redistribution which could be driving the inequality-innovation relationship. This is because of the famous Meltzer-Richard hypothesis (Meltzer and Richard 1981) according to which a higher level of pre-tax pre-transfer inequality leads to more demand for redistribution that can be effectively realized in a majority-voting political system. The positive relationship between pre-tax pre-transfer income inequality and redistribution has been confirmed empirically (Gründler and Köllner 2017). For this reason, we account for both pre-tax pre-transfer inequality and income redistribution in our empirical models exploring the relationship between redistribution and innovation.

In this paper, we are concerned with testing if income redistribution affects innovation, controlling for the level of pre-tax pre-transfer income inequality. In principle, several mechanisms link redistribution and innovation. Redistribution refers to all policies that transform the pre-tax pre-transfer income distribution into post-tax post-transfer distribution. They include direct and indirect taxation as well as cash transfers and in-kind transfers (public spending on education, health, and other services). Several studies explored recently the impact of higher income taxes imposed on (top) innovators. Akcigit et al. (2018) show that personal (and corporate) income taxes hurt both the quantity and quality of innovation in the United States during the 20th century. Higher income taxes give also incentives for shifting innovation activities across the US states. Akcigit et al. (2016) provide evidence that higher top income tax rates increase significantly international mobility of superstar inventors. However, these studies found that inventors are much less sensitive to taxation when there is a lot of research or innovation activity in the location that they reside in. This suggests that using tax policy for redistribution could be less impeding for innovation or could even have a positive effect if the tax revenues are used for providing better amenities and infrastructure for innovation (Akcigit and Stantcheva 2020). Redistribution can also enhance innovation through human capital policies (Van Reenen 2020). This could work by increasing the supply of STEM workers via public funding or subsidizing universities as well as through directing more government grant funding for research and development. Additionally, Bell et al. (2019a, b) show that aggregate innovation could be increased significantly if high-ability potential inventors coming from disadvantaged groups (such as women, minorities, children from low-income families) were targeted at an early age by policies that expand their opportunities.

Overall, it seems that the effect of redistributive policies on innovation is ambiguous theoretically. Depending on the size and design of taxes and transfers contributing to redistribution the effect could be negative or positive. The latter could be obtained in practice, for instance, by relying more on indirect (sales or value-added taxes) than direct taxation for collecting revenues and directing social transfers more towards the in-kind redistribution such as amenities for innovation and investing more in education and health services for the poor and the lower middle class. Overall, the direction of the impact of redistribution on innovation should be tested empirically.

\section{Data and methods}

\subsection{Income inequality and redistribution data from Distributional National Accounts}

We use inequality and redistribution data from the recently compiled novel Distributional National Accounts (DINA) that provide harmonized, cross-country comparable information on the distribution of country's entire national income consistent with macroeconomic aggregates from the System of National Accounts (Alvaredo et al. 2020a, b). ${ }^{4}$ Before constructing DINA, inequality and redistribution studies relied exclusively on income data taken from household

\footnotetext{
${ }^{4}$ The data are available from the World Inequality Database project (WID.world) webpage.
} 
surveys or fiscal statistics. However, income data from these sources are far from perfect. Household surveys offer self-reported data that often heavily underrepresent top incomes, while income tax data do not provide incomes of non-taxpayers. In consequence, estimates of levels and trends in household incomes and of resulting distributional measures can be severely biased (Alvaredo et al. 2018; Nolan et al. 2019). On the other hand, the DINA database combines data from income tax sources, household surveys and national accounts (including tax-exempt capital income and undistributed profits) in a way that provides much more complete estimates of the income distribution in the whole population. For instance, to be consistent with national accounts income concepts in the DINA include corporate retained earnings and imputed rents. From the perspective of the present paper, another important advantage of the DINA is that it provides much more comprehensive information on redistribution of national income than databases based on survey or tax data alone. Since it provides data consistent with information from national accounts, the DINA database accounts for all forms of taxes and transfers which are usually missed in survey-based data (in-kind redistribution, indirect taxes, etc). Moreover, the DINA captures much better the top of income distribution as it exploits administrative data from income tax returns.

The DINA project provides inequality and redistribution measures in terms of several income concepts (Alvaredo et al. 2020a, b). We use distributional series based on the pre-tax national income and post-tax national income. The former is defined as the sum of all income flows accruing to the individual owners of labour and capital before the operation of the tax and transfer system, but after the operation of the pension and unemployment insurance systems. Post-tax national equals pre-tax national income minus all taxes on income, production and wealth plus all cash and in-kind transfers. Hence, redistribution transforming pre-tax into posttax income distribution refers within this framework to all government policies (including direct and indirect taxation as well as cash and in-kind transfers such as health or education) except for (public and private) retirement and unemployment benefits which are treated rather as social insurance mechanisms. ${ }^{5}$ We follow many recent contributions (see, e.g., Marx et al. 2016; Guillaud et al. 2020; Blanchet et al. 2020) in treating old-age pensions as insurance and non-redistributive transfers. This is because most of the elderly population has no other income than pensions and excluding pensions from the pre-tax income distribution would exaggerate the pre-tax inequality as well as making it very sensitive to the age structure of population in a cross-country comparison. Moreover, as observed by Blanchet et al. (2020) the redistributive element in pension systems of the European countries is rather small.

We use income redistribution measures based on three inequality indices $I$ : top $1 \%$ and top $10 \%$ income shares and the Gini index. For a pre-tax income distribution, $X^{\text {Pre-tax }}$, and a post-tax income distribution, $X^{\text {Post-tax }}$, redistribution, $R$, is usually measured (see, e.g., Gründler and Köllner 2017) as a difference between inequality of pre-tax and inequality of post-tax income distribution:

$$
R_{i t}^{I}=I\left(X^{\text {Pre-tax }}\right)_{i t}-I\left(X^{\text {Post-tax }}\right)_{i t},
$$

where $I$ is an inequality index, $i$ denotes countries, and $t$ - time periods. ${ }^{6}$ At present, the DINA provides data that allow computing redistribution indices for 34 advanced and emerging countries (all European countries plus Canada and the US) observed mostly since 1980. To ensure that our results are not driven by sample selection, we conducted robustness checks using survey-based inequality and redistribution indices from the Standardized World Income Inequality

\footnotetext{
${ }^{5}$ In section 4.2, we conduct a robustness test measuring redistribution from pre-tax national income to post-tax disposable income which excludes in-kind transfers.

${ }^{6}$ In a robustness section, we also use an alternative redistribution indicator, $R_{i t}^{I} / I\left(X^{\text {Pre-tax }}\right)_{i t} * 100$, which measures relative redistribution as a percentage reduction in pre-tax inequality due to the redistribution.
} 
Database, SWIID, (Solt 2020) that have been extensively used in previous research on inequality and innovation (see, e.g., Benos and Tsiachtsiras 2019; Law et al. 2020).

\subsection{Measures of innovation}

We follow the literature on inequality and innovation in using patent-based measures of innovation (Antonelli and Gehringer 2016; Aghion et al. 2019; Benos and Tsiachtsiras 2019). Our first quantity indicator is the number of patents granted per year of application (patent counts) from the US Patent and Trademark Office (USPTO). ${ }^{7}$ Additionally, we use two quality-related measures of innovation: patent citations and patent originality. Patent citations refer to the overall number of citations received by patents granted to applicants from a given country in a given year. Patent originality is defined as one minus the Herfindahl concentration index of citations of previous patents belonging to different technology categories (Hall et al. 2001). Patents citing patents in a wide range of technology fields have high originality and potential to be more impactful. We use data on these three innovation proxies as collected by Gao et al. (2017) for the period 1964-2010.

\subsection{Empirical framework}

We regress the log of our innovation indicators on their (one-year) lagged values, the redistribution measure (1) and its corresponding inequality index as well as control variables. Our estimated equation is:

$$
\operatorname{Ln}\left(\text { Innov }_{i t}+1\right)=\operatorname{Ln}\left(\operatorname{Innov}_{i t-1}+1\right)+\beta_{1} R_{i t}^{I}+\beta_{2} I_{i t}+\beta_{3} X_{i t}+c_{i}+\alpha_{t}+\varepsilon_{i t},
$$

where Innov $v_{i t}$ is a measure of innovation (patent counts, patent citations or patent originality), $R_{i t}$ is a redistribution measure (1), $I_{i t}$ is an inequality index (top 10\% income share, top $1 \%$ income share or the Gini coefficient), $X$ is a vector of control variables, $c$ is a country fixed effect and $\alpha$ is a time fixed effect. To avoid missing values when an innovation index takes the value of 0 , we add 1 to all values of innovation measures. Control variables include education level, the log of the GDP per capita, log of population and population density, urbanization rate and an indicator of economic openness (Gao et al. 2017). Summary statistics are reported in Supplementary Appendix A (Table A1).

We include the lagged dependent variable among explanatory variables to account for the persistence of innovation measures at the country level. The persistence is due to the cumulative nature of innovation activities driven by loops and feedback effects between past and present innovation (Tselios 2011). ${ }^{8}$ The equation (2) is a standard dynamic panel data model with two-way fixed effects. ${ }^{9}$ It is well-known that the OLS (with the so-called least squares dummy variable, LSDV, estimator) estimator applied to (2) is biased and inconsistent when the time dimension of the panel $(T)$ is small. Since in our case $T$ at most rather moderate $(T=23.7$

\footnotetext{
${ }^{7}$ We also explored the use of the worldwide count of patent priority filings introduced by de Rassenfosse et al. (2013). This measure of innovative activity is based on counting all the priority patent applications filed by residents of a country regardless of the patent office of application. Our results were robust to the use of this indicator. ${ }^{8}$ Guarascio and Tamagni (2019) show that there is relatively litte innovation persistence at the firm level, especially when innovation is measured by patenting activity (Guarascio and Tamagni 2019). On the other hand, empirical studies have shown that at the country level innovation in the current period significantly depends on innovation in the previous period (Tselios 2011; Wang et al. 2019).

${ }^{9}$ Since many authors (see, e.g., Kropko and Kubinec 2020; de Chaisemartin and d'Haultfoeuille 2020) have shown recently that two-way fixed effects models (with time and case fixed effects) suffer from methodological and interpretational difficulties, we estimated all models also with one-way (either time or country) fixed effects. The results are robust to this modification.
} 
on average in case of modelling log of patent counts), we estimate (2) using the least squares dummy variable bias-corrected (LSDVC) estimator derived by Kiviet (1995) and extended to unbalanced panel data by Bruno (2005a). ${ }^{10}$

The dynamic panel data models are usually estimated using the difference GMM estimator (Arellano and Bond 1991) and the system GMM estimator (Blundell and Bond 1998). However, these estimators are consistent when the number of cross-sectional units, $N$, is large. This is not the case of our sample which consists of at most 34 countries. Simulation studies have shown that LSDVC outperforms the GMM and other estimators with respect to the bias and root mean squared error criteria for sample sizes comparable to those used in the present paper (Bruno 2005b). Another advantage of the GMM estimators is that they offer protection against endogeneity bias (i.e. reverse causality) by exploiting internal instruments constructed using lagged levels and differences of the regressors. Therefore, we complement our baseline results based on the LSDVC estimator with those based on the system GMM estimator which is more efficient than the difference GMM estimator and has better small-sample properties.

\section{Results}

\subsection{Income redistribution and innovation - baseline results}

Table 1 reports our baseline estimates for income redistribution based on top income shares and innovation proxied by (log of) our three innovation indicators. The coefficients for redistribution are positive but statistically insignificant across all models. In line with all other studies, the GDP per capita is positively related to innovation. Lagged values of all innovation measures are highly significant and positively associated with present innovation implying strong persistence of innovation in a cross-country setting. Top income shares are negatively associated with innovation and marginally significant in case of patent citations as well as for the top $10 \%$ income share and patent originality. This is consistent with the recent results of Benos and Tsiachtsiras (2019) who found a negative association between inequality and several measures of innovation in a panel of 29 countries. ${ }^{11}$ On the other hand, we do not find a significant relationship between any measure of income inequality and innovation measured using patent counts. This suggests that inequality may have a more pronounced effect on the quality of innovation and lesser or no effect on the quantity of it.

Table 2 investigates the redistribution-innovation relationship using the Gini index, which in contrast to top income shares does not concentrate on top incomes but takes into account differences in income among all pairs of individuals in a society. Focusing on inequality and redistribution based on a broad inequality measure like the Gini index allows verifying if the tax and transfer system affects innovation not mainly though adjusting income distribution at the top, but also in the middle and at the bottom. We use the Gini estimates coming from the DINA as well as those based only on household survey data from the SWIID (Solt 2020). Across all model specifications, coefficients on income redistribution indicators are insignificant confirming our results based on top income shares. Confirming results based on top income shares, the Gini from DINA is negatively and significantly related to innovation measures reflecting patent quality (patent citations and patent originality). On the other hand, survey-based Gini data from SWIID produce positive (column 2) or insignificant (columns 4 and 6) estimates of the inequality-innovation relationship.

\footnotetext{
${ }^{10}$ In particular, we use a version of the LSDVC that provides bias approximation of the order $N^{-1} \bar{T}^{-2}$, where $N$ is the number of countries and $\bar{T}$ is the average number of years per country in the sample.

${ }^{11}$ Benos and Tsiachtsiras (2019) found not only a negative association between one-year lagged innovation and top income shares, but also a negative causal effect of innovation on income inequality based on instrumental variable estimation.
} 
Table 1. Income redistribution based on top income shares and three measures of innovative activity - LSDVC estimates

\begin{tabular}{|c|c|c|c|c|c|c|}
\hline & \multicolumn{2}{|c|}{ Ln (patent counts) } & \multicolumn{2}{|c|}{ Ln (patent citations) } & \multicolumn{2}{|c|}{ Ln (patent originality) } \\
\hline & $(1)$ & $(2)$ & (3) & $(4)$ & $(5)$ & $(6)$ \\
\hline \multirow[t]{2}{*}{ Lagged dependent variable } & $0.692^{* * *}$ & $0.693^{* * *}$ & $0.149^{* * *}$ & $0.164^{* * *}$ & $0.393^{* * *}$ & $0.408^{* * *}$ \\
\hline & $(0.032)$ & $(0.032)$ & $(0.049)$ & $(0.050)$ & $(0.048)$ & $(0.048)$ \\
\hline \multirow[t]{2}{*}{ Redistribution } & 0.023 & 0.042 & 0.027 & 0.201 & 0.051 & 0.102 \\
\hline & $(0.016)$ & $(0.025)$ & $(0.125)$ & $(0.169)$ & $(0.059)$ & $(0.083)$ \\
\hline \multirow[t]{2}{*}{ Top $10 \%$ share (pre-tax) } & -0.011 & & $-0.082^{*}$ & & $-0.039^{*}$ & \\
\hline & $(0.007)$ & & $(0.046)$ & & $(0.022)$ & \\
\hline \multirow[t]{2}{*}{ Top 1\% share (pre-tax) } & & -0.016 & & $-0.119^{*}$ & & -0.048 \\
\hline & & $(0.011)$ & & $(0.068)$ & & $(0.034)$ \\
\hline \multirow[t]{2}{*}{ Years of secondary schooling } & -0.044 & -0.038 & 0.074 & 0.091 & -0.040 & -0.025 \\
\hline & $(0.041)$ & $(0.041)$ & $(0.220)$ & $(0.221)$ & $(0.109)$ & $(0.111)$ \\
\hline \multirow[t]{2}{*}{ Ln (GDP per capita) } & $0.682^{* * *}$ & $0.694^{* * * *}$ & $2.627^{* * *}$ & $2.602^{* *}$ & $1.330^{* * *}$ & $1.339^{* *}$ \\
\hline & $(0.171)$ & $(0.172)$ & $(1.113)$ & $(1.083)$ & $(0.552)$ & $(0.552)$ \\
\hline \multirow[t]{2}{*}{ Ln (population) } & -6.441 & -6.809 & 46.894 & 60.388 & -4.515 & -1.250 \\
\hline & $(8.465)$ & $(8.507)$ & $(294.547)$ & $(289.241)$ & $(140.819)$ & $(141.879)$ \\
\hline \multirow[t]{2}{*}{ Ln (population density) } & 6.510 & 7.043 & -42.545 & -55.015 & 5.736 & 2.917 \\
\hline & $(8.516)$ & $(8.564)$ & $(294.830)$ & $(289.514)$ & (140.969) & (142.024) \\
\hline \multirow[t]{2}{*}{ Urban population ( $\%$ of total) } & $-0.014^{*}$ & $-0.014^{*}$ & 0.005 & 0.002 & 0.009 & 0.009 \\
\hline & $(0.008)$ & $(0.008)$ & $(0.051)$ & $(0.049)$ & $(0.024)$ & $(0.024)$ \\
\hline \multirow[t]{2}{*}{ Openness } & -0.001 & -0.001 & 0.001 & 0.001 & 0.002 & 0.001 \\
\hline & $(0.001)$ & $(0.001)$ & $(0.011)$ & $(0.010)$ & $(0.005)$ & $(0.005)$ \\
\hline Observations & 805 & 805 & 557 & 557 & 557 & 557 \\
\hline Number of countries & 34 & 34 & 31 & 31 & 31 & 31 \\
\hline
\end{tabular}

Table 2. Income redistribution based on the Gini index and three measures of innovative activity - LSDVC esti$\underline{\text { mates }}$

\begin{tabular}{|c|c|c|c|c|c|c|}
\hline & \multicolumn{2}{|c|}{ Ln (patent counts) } & \multicolumn{2}{|c|}{ Ln (patent citations) } & \multicolumn{2}{|c|}{ Ln (patent originality) } \\
\hline & (1) & $(2)$ & (3) & (4) & $(5)$ & (6) \\
\hline \multirow[t]{2}{*}{ Lagged dependent variable } & $0.688^{* * *}$ & $0.683^{* * *}$ & $0.146^{* * *}$ & $0.417^{* * *}$ & $0.415^{* * *}$ & $0.684^{* * *}$ \\
\hline & $(0.030)$ & $(0.015)$ & $(0.048)$ & $(0.031)$ & $(0.046)$ & $(0.025)$ \\
\hline \multirow[t]{2}{*}{ Redistribution } & 0.018 & -1.607 & 0.003 & 7.453 & 0.055 & 1.239 \\
\hline & $(0.012)$ & $(1.660)$ & $(0.113)$ & $(5.324)$ & $(0.054)$ & $(3.932)$ \\
\hline \multirow[t]{2}{*}{ Gini index (pre-tax), DINA } & -0.007 & & $-0.074^{*}$ & & $-0.039^{*}$ & \\
\hline & $(0.006)$ & & $(0.044)$ & & $(0.022)$ & \\
\hline \multirow[t]{2}{*}{ Gini index (pre-tax), SWIID } & & $0.017^{* *}$ & & -0.004 & & -0.009 \\
\hline & & $(0.007)$ & & $(0.030)$ & & $(0.024)$ \\
\hline \multirow[t]{2}{*}{ Years of secondary schooling } & -0.047 & 0.039 & 0.093 & -0.092 & -0.042 & -0.016 \\
\hline & $(0.043)$ & $(0.044)$ & $(0.237)$ & $(0.113)$ & $(0.119)$ & $(0.090)$ \\
\hline \multirow[t]{2}{*}{ Ln (GDP per capita) } & $0.744^{* * *}$ & $0.590^{* * *}$ & $2.678^{* *}$ & $1.814^{* * *}$ & $1.367^{* *}$ & $0.879^{* * *}$ \\
\hline & $(0.174)$ & $(0.079)$ & $(1.262)$ & $(0.373)$ & $(0.635)$ & $(0.261)$ \\
\hline \multirow[t]{2}{*}{ Ln (population) } & -6.532 & 2.223 & 33.354 & 0.353 & -7.416 & 3.084 \\
\hline & $(8.977)$ & $(2.184)$ & $(306.843)$ & $(8.233)$ & $(148.910)$ & $(6.175)$ \\
\hline \multirow[t]{2}{*}{ Ln (population density) } & 6.656 & -2.142 & -28.607 & 1.481 & 8.300 & -2.136 \\
\hline & $(9.051)$ & $(2.188)$ & $(307.104)$ & $(8.318)$ & $(149.061)$ & $(6.229)$ \\
\hline \multirow[t]{2}{*}{ Urban population ( $\%$ of total) } & -0.014 & $0.012^{* * *}$ & 0.002 & 0.026 & 0.007 & 0.002 \\
\hline & $(0.009)$ & $(0.004)$ & $(0.051)$ & $(0.019)$ & $(0.026)$ & $(0.014)$ \\
\hline \multirow[t]{2}{*}{ Openness } & -0.002 & 0.001 & -0.001 & -0.002 & 0.000 & -0.001 \\
\hline & $(0.001)$ & $(0.001)$ & $(0.012)$ & $(0.003)$ & $(0.006)$ & $(0.002)$ \\
\hline Observations & 808 & 3198 & 567 & 1306 & 567 & 1309 \\
\hline Number of countries & 33 & 118 & 30 & 74 & 30 & 74 \\
\hline
\end{tabular}


Table 3. Income redistribution (based on top income shares and the Gini index) and three measures of innovative activity system GMM estimates

\begin{tabular}{|c|c|c|c|c|c|c|c|c|c|}
\hline & \multicolumn{3}{|c|}{ Ln (patent counts) } & \multicolumn{3}{|c|}{ Ln (patent citations) } & \multicolumn{3}{|c|}{ Ln (patent originality) } \\
\hline & $(1)$ & $(2)$ & (3) & (4) & $(5)$ & (6) & $(7)$ & (8) & $(9)$ \\
\hline Lagged dependent variable & $\begin{array}{c}0.994^{* * * *} \\
(0.020)\end{array}$ & $\begin{array}{l}1.014^{* * * *} \\
(0.024)\end{array}$ & $\begin{array}{c}0.947^{\text {**** }} \\
(0.039)\end{array}$ & $\begin{array}{c}0.944^{* * * *} \\
(0.237)\end{array}$ & $\begin{array}{c}0.956^{\text {**** }} \\
(0.305)\end{array}$ & $\begin{array}{l}0.821^{* *} \\
(0.384)\end{array}$ & $\begin{array}{c}0.953^{* * * *} \\
(0.083)\end{array}$ & $\begin{array}{c}0.998^{* * * *} \\
(0.061)\end{array}$ & $\begin{array}{c}0.871^{\text {***** }} \\
(0.132)\end{array}$ \\
\hline Redistribution & $\begin{array}{c}0.008 \\
(0.023)\end{array}$ & $\begin{array}{c}0.001 \\
(0.031)\end{array}$ & $\begin{array}{c}0.004 \\
(0.022)\end{array}$ & $\begin{array}{c}0.181 \\
(0.310)\end{array}$ & $\begin{array}{c}0.143 \\
(0.192)\end{array}$ & $\begin{array}{c}0.071 \\
(0.505)\end{array}$ & $\begin{array}{c}0.121 \\
(0.084)\end{array}$ & $\begin{array}{c}0.058 \\
(0.088)\end{array}$ & $\begin{array}{c}0.087 \\
(0.093)\end{array}$ \\
\hline Top $10 \%$ share (pre-tax) & $\begin{array}{c}0.004 \\
(0.015)\end{array}$ & & & $\begin{array}{l}-0.485^{*} \\
(0.286)\end{array}$ & & & $\begin{array}{l}-0.142 \\
(0.103)\end{array}$ & & \\
\hline Top $1 \%$ share (pre-tax) & & $\begin{array}{c}0.009 \\
(0.037)\end{array}$ & & & $\begin{array}{c}-0.249^{* *} \\
(0.116)\end{array}$ & & & $\begin{array}{l}-0.100^{*} \\
(0.057)\end{array}$ & \\
\hline Gini index (pre-tax) & & & $\begin{array}{c}-0.031 \\
(0.032)\end{array}$ & & & $\begin{array}{c}-0.444 \\
(0.425)\end{array}$ & & & $\begin{array}{c}-0.118 \\
(0.087)\end{array}$ \\
\hline Constant & $\begin{array}{c}-0.147 \\
(0.407)\end{array}$ & $\begin{array}{l}-0.172 \\
(0.319)\end{array}$ & $\begin{array}{c}1.281 \\
(1.306)\end{array}$ & $\begin{array}{r}13.704 \\
(8.845)\end{array}$ & $\begin{array}{c}2.080 \\
(2.742)\end{array}$ & $\begin{array}{c}17.339 \\
(19.632)\end{array}$ & $\begin{array}{c}4.015 \\
(2.910)\end{array}$ & $\begin{array}{l}0.928^{* *} \\
(0.414)\end{array}$ & $\begin{array}{c}4.612 \\
(3.208) \\
\end{array}$ \\
\hline Observations & 525 & 525 & 510 & 319 & 319 & 306 & 319 & 319 & 306 \\
\hline Number of countries & 38 & 38 & 37 & 33 & 33 & 32 & 33 & 33 & 32 \\
\hline Number of instruments & 33 & 33 & 33 & 31 & 31 & 31 & 31 & 31 & 31 \\
\hline AR (1) test (p-value) & 0.000 & 0.000 & 0.001 & 0.020 & 0.042 & 0.150 & 0.018 & 0.009 & 0.024 \\
\hline AR (2) test (p-value) & 0.738 & 0.702 & 0.857 & 0.052 & 0.049 & 0.080 & 0.087 & 0.265 & 0.195 \\
\hline Hansen test (p-value) & 0.204 & 0.137 & 0.198 & 0.434 & 0.603 & 0.137 & 0.240 & 0.154 & 0.270 \\
\hline
\end{tabular}

Note: ${ }^{*} p<0.10,{ }^{* *} p<0.05,{ }^{* * *} p<0.01$. Income redistribution is defined as a difference between pre-tax and posttax inequality measured using a given inequality index. Redistribution and inequality are measured at time $t$, while innovation is averaged over $t$ and $t+1$. See section 3 for a definition of other variables. All models include country and time fixed effects.

To account the endogeneity of inequality and redistribution variables, we complement our baseline results with those estimated using the system GMM method. ${ }^{12}$ Following the literature, reverse causality and measurement error are addressed by relying on 2-year non-overlapping time intervals with redistribution and inequality measured at time $t$ and innovation averaged over $t$ and $t+1 .^{13}$ The internal instruments exploited by the system GMM estimator are constructed using levels and differences of the second lag of the dependent variable and first through fourth lag of inequality and redistribution variables. Table 3 presents the results based on the system GMM estimator. Model specification and instrument validity are in general confirmed by the expected values of the Hansen test for overidentifying restrictions and the first and second-order residual autocorrelation tests. The results confirm our baseline findings from Tables 1-2. Coefficients on redistribution variable are positive but statistically insignificant. Top income shares seem to be reducing innovation as measured by patent citations. The results using the system GMM estimator are not sensitive to various specification choices regarding instrument construction and selection of control variables.

\subsection{Robustness analysis}

The results from Tables 1-3 are robust to a variety of sensitivity checks. Below, we briefly summarize the outcomes of these tests, while full results are presented in the Supplementary Appendix A. We do not find a significant and negative relationship between innovation and lagged values of redistribution variables (with lags up to three years) or when the analysis is restricted to subsamples (the OECD countries, high-income countries, or the sample excluding post-socialist economies) (see Appendix A, Tables A5-A7, A10-A12). There is also no evidence of nonlinearities in the effect of tax and transfer policies on innovation in our cross-

\footnotetext{
${ }^{12}$ See, for instance, Tselios (2011) and De Palo et al. (2018) for the use of this approach in the context of the inequality-innovation link.

${ }^{13}$ Other choices for time structure of the data set, for instance using 5-year time intervals, do not change our conclusions (detailed results available upon request).
} 
country setting. In principle, it could be that redistribution is either detrimental, benign or even beneficial for innovation depending on the size of the redistributive effect. To study this kind of nonlinearities, we construct dummy variables representing pre-tax inequality and income redistribution at the top $25 \%$ and bottom $75 \%$ of the relevant distributions of inequality and redistribution variables. ${ }^{14} \mathrm{We}$ do not find any evidence for a significant nonlinear redistributioninnovation relationship (Tables A8-A9). In particular, very large redistributive effects (higher than the top 25th percentile of all redistribution observations) do not seem to hurt innovation. This result is robust to other definitions of large redistributive effects (such as the 90th percentile of all redistribution values).

Replacing the absolute redistribution measure defined in equation (1) by a relative redistribution index $R_{i t}^{I} / I\left(X^{\text {Pre-tax }}\right)_{i t} * 100$ does not change the insignificance of our baseline estimates of redistribution coefficients (Table A13). The results are also robust when our baseline inequality indices based on post-tax national income distribution are replaced by inequality measures computed using post-tax disposable income excluding in-kind transfers (i.e. health, education and other public spending) (Table A14). The latter is a less comprehensive income measure but does not require making strong assumptions on how public spending is distributed among individuals.

Finally, we also tested whether the effect of redistribution on innovation depends on the level of the country's technological development. Potentially, income redistribution could affect innovation differently in low-innovation countries than in high-innovation countries. For instance, larger redistribution in the latter group of countries, especially if driven by high marginal income tax rates for top-income earners, could have a stronger negative effect on innovation. To test for this possibility, we estimated a variant of equation (2) using a quantile regression approach with two-way fixed effects (Machado and Silva 2019). ${ }^{15}$ Results show that redistribution is never negatively associated with quantiles of cross-country distribution of innovation measures (Tables A15-A17).

\section{Conclusions}

This paper provides the first attempt to study how overall income redistribution through the joint effect of tax and transfer policies affects innovation in a cross-country setting. Using a novel, high-quality dataset on income redistribution, we do not find any negative impact of redistributive policies on several patent-based innovation indicators in a sample of 34 developed countries observed over 1980-2010. The present paper provides first evidence suggesting that taken together tax and transfer policies may be harmless for countries' overall innovation performance. If confirmed by other studies, our results could imply that pursuing more redistribution to reduce prevailing levels of income inequality does not hurt innovation and its benefits for economic growth and development.

However, several limitations should be kept in mind while interpreting our results. Due to the limited availability of data, most of the analysis has been restricted to a sample of advanced and emerging countries (all European countries, the United States and Canada). Therefore, it might be that the effect of tax and transfer policies is less benign when less developed countries are taken into account. ${ }^{16}$ Additionally, our results do not imply that a more extreme income redistribution than observed in our sample would be harmless for innovation. To the

\footnotetext{
${ }^{14}$ A similar approach was applied by Berg et al. (2018) to study nonlinearities in the inequality-growth relationship.

15 The dependent variables were different quantiles (Q10, Q25, Q50, Q75, Q90) of the distribution of our patentbased innovation measures. Quantile regression has been previously used by, among others, Antonelli and Gehringer (2017) to study the differential effect of innovation on income inequality.

${ }^{16}$ However, it should be noted that the analysis using the Gini indices from SWIID covers up to 118 countries (see Table 2).
} 
contrary, a more extreme redistribution scheme, especially if driven by significantly increased average income tax rate or radical tax progressivity, could be a major impeding factor for the overall innovation on a country level.

The analysis in this paper is conducted in a highly-aggregated cross-country setting. We used overall income redistribution measures without decomposing them into contributions of different income taxes and social transfers. However, it seems obvious that the design of income redistribution matters for innovation. In particular, innovation at the country level could be affected differently by redistribution systems of the same scale but with the varying overall average tax rate, design of the tax system concerning direct versus indirect taxation, the parameters of taxes imposed on labour versus capital income, degree of progressivity of income taxation, the composition of cash versus in-kind social transfers, and allocation of transfers to different uses (e.g. human capital formation or subsidizing research versus cash transfers to all households with little overall redistributive efficiency). Our paper does not address also the important issue of the effect of wealth taxation on innovation. Future studies should investigate carefully how the design and structure of redistribution policies affect innovation activities.

We should also stress that while we found no effect of redistribution on innovation on a country level, such an effect could appear on a within-country regional or local level. Moreover, we studied overall countries' innovation while the negative impact of redistribution may manifest itself rather on individual innovative activity, especially in the case of the top or 'superstar' innovators. ${ }^{17}$ These avenues should be pursued in future research using international panel data on patenting behaviour of individual innovators.

\section{References}

Aghion, P., Akcigit, U., Bergeaud, A., Blundell, R., \& Hémous, D. (2019). Innovation and top income inequality. The Review of Economic Studies, 86(1), 1-45.

Akcigit, U., Baslandze, S., \& Stantcheva, S. (2016). Taxation and the international mobility of inventors. American Economic Review, 106(10), 2930-81.

Akcigit, U., Grigsby, J., Nicholas, T., \& Stantcheva, S. (2018). Taxation and Innovation in the 20th Century (No. w24982). National Bureau of Economic Research.

Akcigit, U., \& Stantcheva, S. (2020). Taxation and Innovation: What Do We Know? (No. w27109). National Bureau of Economic Research.

Alvaredo, F., Chancel, L., Piketty, T., Saez, E., \& Zucman, G. (Eds.). (2018). World inequality report 2018. Belknap Press.

Alvaredo, F., Atkinson, A. B., Blanchet, T., Chancel, L., Bauluz, L., Fisher-Post, M., Flores, I., Garbinti, B., Goupille-Lebret, J., Martinez-Toledano, C., Morgan, M., Neef, T., Piketty, T., Robilliard, A-S., Saez, E., Yang, L., Zucman G. (2020a). Distributional National Accounts Guidelines 2020: Methods and Concepts used in the World Inequality Database. https://wid.world/document/distributional-national-accounts-guidelines-2020-conceptsand-methods-used-in-the-world-inequality-database/

Alvaredo, F., Chancel, L., Piketty, T., Saez, E., \& Zucman, G. (2020b). Towards a System of Distributional National Accounts: Methods and Global Inequality Estimates from WID. world. Economie et Statistique / Economics and Statistics, 517-518-519, 41-59.

Antonelli, C., \& Gehringer, A. (2017). Technological change, rent and income inequalities: A Schumpeterian approach. Technological Forecasting and Social Change, 115, 85-98.

\footnotetext{
${ }^{17}$ See, for instance, Akcigit et al. (2016) for a study showing that top income tax rates affect significantly the international mobility of superstar inventors. However, this paper considers only the effect of income taxes without taking into account how increased redistribution from top income taxation affects overall innovation activities of countries.
} 
Arellano, M., \& Bond, S. (1991). Some tests of specification for panel data: Monte Carlo evidence and an application to employment equations. The Review of Economic Studies, 58(2), 277-297.

Bell, A., Chetty, R., Jaravel, X., Petkova, N., \& Van Reenen, J. (2019a). Do tax cuts produce more Einsteins? The impacts of financial incentives versus exposure to innovation on the supply of inventors. Journal of the European Economic Association, 17(3), 651-677.

Bell, A., Chetty, R., Jaravel, X., Petkova, N., \& Van Reenen, J. (2019b). Who becomes an inventor in America? The importance of exposure to innovation. The Quarterly Journal of Economics, 134(2), 647-713.

Benos, N., \& Tsiachtsiras, G. (2019). Innovation and Income Inequality: World Evidence. MPRA Paper No. 92050.

Berg, A., Ostry, J. D., Tsangarides, C. G., \& Yakhshilikov, Y. (2018). Redistribution, inequality, and growth: new evidence. Journal of Economic Growth, 23(3), 259-305.

Blanchet, T., Chancel, L., \& Gethin, A. (2020). Why is Europe more equal than the United States? WID. world Working Paper 2020/19.

Blundell, R., \& Bond, S. (1998). Initial conditions and moment restrictions in dynamic panel data models. Journal of Econometrics, 87(1), 115-143.

Bruno, G. S. (2005a). Approximating the bias of the LSDV estimator for dynamic unbalanced panel data models. Economics Letters, 87(3), 361-366.

Bruno, G. S. (2005b). Estimation and inference in dynamic unbalanced panel-data models with a small number of individuals. The Stata Journal, 5(4), 473-500.

Chancel, L. (2019). Ten facts about inequality in advanced economies. Forthcoming in "Combating Inequality: Rethinking Policies to Reduce Inequality in Advanced Economies" (eds. O. Blanchard, D. Rodrik), MIT Press.

de Chaisemartin, C., \& d'Haultfoeuille, X. (2020). Two-way fixed effects estimators with heterogeneous treatment effects. American Economic Review, 110(9), 2964-96.

De Palo, C., Karagiannis, S., \& Raab, R. (2018). Innovation and inequality in the EU: for better or for worse?. Publications Office of the European Union, JRC112623.

de Rassenfosse, G., Dernis, H., Guellec, D., Picci, L., \& de la Potterie, B. V. P. (2013). The worldwide count of priority patents: A new indicator of inventive activity. Research Policy, 42(3), 720-737.

Gao, Y., Zang, L., Roth, A., \& Wang, P. (2017). Does democracy cause innovation? An empirical test of the popper hypothesis. Research Policy, 46(7), 1272-1283.

Gründler, K., \& Köllner, S. (2017). Determinants of governmental redistribution: Income distribution, development levels, and the role of perceptions. Journal of Comparative Economics, 45(4), 930-962.

Guarascio, D., \& Tamagni, F. (2019). Persistence of innovation and patterns of firm growth. Research Policy, 48(6), 1493-1512.

Guillaud, E., Olckers, M., \& Zemmour, M. (2020). Four levers of redistribution: The impact of tax and transfer systems on inequality reduction. Review of Income and Wealth, 66(2), 444-466.

Hall, B. H., Jaffe, A. B., \& Trajtenberg, M. (2001). The NBER patent citation data file: Lessons, insights and methodological tools (No. w8498). National Bureau of Economic Research.

Jones, C. I., \& Kim, J. (2018). A Schumpeterian model of top income inequality. Journal of Political Economy, 126(5), 1785-1826.

Kiviet, J. F. (1995). On bias, inconsistency, and efficiency of various estimators in dynamic panel data models. Journal of Econometrics, 68(1), 53-78.

Kropko, J., \& Kubinec, R. (2020). Interpretation and identification of within-unit and crosssectional variation in panel data models. PLoS One, 15(4), e0231349. 
Law, S. H., Naseem, N. A. M., Lau, W. T., \& Trinugroho, I. (2020). Can innovation improve income inequality? Evidence from panel data. Economic Systems.

Lee, N. (2011). Are innovative regions more unequal? Evidence from Europe. Environment and Planning C: Government and Policy, 29(1), 2-23.

Machado, J. A., \& Silva, J. S. (2019). Quantiles via moments. Journal of Econometrics, 213(1), 145-173.

Marx, I., Salanauskaite, L. Verbist, G. (2016). For the Poor, but Not Only the Poor: On Optimal Pro-Poorness in Redistributive Policies. Social Forces, 95, 1-24.

Meltzer, A. H., \& Richard, S. F. (1981). A rational theory of the size of government. Journal of Political Economy, 89(5), 914-927.

Nolan, B., Roser, M., \& Thewissen, S. (2019). GDP per capita versus median household income: What gives rise to the divergence over time and how does this vary across OECD countries?. Review of Income and Wealth, 65(3), 465-494.

Nolan, B., \& Valenzuela, L. (2019). Inequality and its discontents. Oxford Review of Economic Policy, 35(3), 396-430.

OECD (2015). In it together: Why less inequality benefits all. Paris, OECD Publishing.

Osório, A., \& Pinto, A. (2020). Income inequality and technological progress: The effect of R\&D incentives, integration, and spillovers. Journal of Public Economic Theory. https://doi.org/10.1111/jpet.12466

Ostry, J. D., Loungani, P., \& Furceri, D. (2016). Neoliberalism: oversold. Finance \& Development, 53(2), 38-41.

Piketty, T. (2014). Capital in the 21st Century. Harvard University Press, Cambridge

Solt, F. (2020). Measuring income inequality across countries and over time: the standardized world income inequality database. Social Science Quarterly, 101(3), 1183-1199.

Stiglitz, J. E. (2012). The price of inequality: How today's divided society endangers our future. WW Norton \& Company.

Tselios, V. (2011). Is inequality good for innovation?. International Regional Science Review, 34(1), 75-101.

Van Reenen, J. (2020). Innovation and Human Capital Policy. In Innovation and Public Policy. University of Chicago Press. Innovation and Public Policy, Austan Goolsbee and Benjamin Jones, editors, Forthcoming from University of Chicago Press, https://www.nber.org/chapters/c14423.

Wang, Q. J., Feng, G. F., Chen, Y. E., Wen, J., \& Chang, C. P. (2019). The impacts of government ideology on innovation: What are the main implications? Research Policy, 48(5), 1232-1247.

Woo, J. (2020). Inequality, redistribution, and growth: new evidence on the trade-off between equality and efficiency. Empirical Economics, 58, 2667-2707. 